\title{
ISLAM AND THE MEDIA OF DEVOTION IN AND OUT OF SENEGAL \\ Beth Buggenhagen
}

Beth Buggenhagen is an Assistant Professor of Anthropology at Indiana University, Bloomington. Her work analyzes the global circuits of Senegalese Muslims and the politics of social production in Senegal.

\begin{abstract}
Few devotees of the Muridiyya, a Sufi congregation that emerged in colonial Senegal at the turn of the twentieth century, have the opportunity to glimpse or touch their spiritual masters. Exalted Murid figures rarely leave their compounds in rural Tuba and access to them is restricted to highranking initiates such as Muslim scholars, government and business leaders. Ordinary disciples are more likely to view religious figures in the variety of media circulating in an out of Senegal. The desire for and appreciation of mediation to facilitate proper practice and proximity to the Divine distinguish Murid adepts from their Sunni counterparts. The electronic mediation of devotional practices produces feelings of nearness to spiritual leaders for disciples in Senegal and abroad. Through visual practices related to electronic media devotees receive religious merit and grace that lead to spiritual and material enrichment and create their spiritual community. [Key words: electronic media, circulation and value, Sufism, Senegal]
\end{abstract}

\section{Islam's New Publicity}

In the evenings during my fieldwork in the Senegalese capital of Dakar in the late 1990s I would often listen to a call and answer show on Radio Dunyaa. Muslim men and women would 
call in and ask questions pertaining to Islam to have them answered by a religious scholar. Radio Dunyaa also broadcast announcements concerning the events, projects and conferences of the Sufi congregations. Every so often, a prominent religious leader known as a shaykh, or a shaykh's spokesperson, would make an announcement in an attempt to rally disciples in support of a major event. During the broadcast, the shaykh would ask the audience: "Do you want me to plug this in? Do you want me to plug this circuit into God?'יi For the $95 \%$ of Senegalese who belong to one of four Sufii ways in Senegal, to be a disciple is to be part of a known way (tariqa) $^{i i i}$ of achieving divine union. To be plugged in is to receive the esoteric litanies that will bring one closer to God.

Murid shaykhs might as well have been talking, though, of the circuits of cash that disciples remit as offerings (hadîya; pl., hadaya) to their spiritual masters from their earnings as merchants and wage laborers in Europe, the United States, the Middle East and China. This circuit consists of the ambit of spiritual power by which blessings (baraka) radiate outwards from God to those who have submitted to God through homage to Sufi shaykhs. For Murid disciples to be "plugged in" offers not just the promise of eternal prosperity but also access to the forms of trade and production through which that prosperity is crafted in the present world.

I first heard this phrase, "plugged in," spoken in a videocassette I watched over a decade ago in Chicago, Illino is at the apartment of a member of a Murid religious association-a recording of the Senegalese television production covering the annual pilgrimage, called the Mággal, of disciples of the Muridiyya to their sacred city of Tuba, in the desert interior of the country. The video that we watched displayed the proceeds of money sent to Tuba-bowls overflowing with food for pilgrims and dignitaries, forms of public and private transport that brought millions of disciples there, and the development of a vast infrastructure to channel 
electricity into and sewage out of the city that disciples had come to witness. Murid congregants circulated these videocassettes and DVDs, to those who were unable to journey in person to the center, for them, of the globalized networks in which they sought fortunes no longer available in Senegal's ecology and economy. Disciples in New York and other global cities often purchased these recordings from shops carrying an assortment of Muslim paraphernalia for Murid adepts. [Figure 1, Murid owned shops in Harlem, New York, 2005]. Overseas disciples also turned to the internet where members of Murid religious associations, called da'ira, constructed websites to facilitate proper practice and disseminated religious knowledge and public events related to their mission. ${ }^{\text {iv }}$

In this paper, I focus on videocassette and DVD productions of religious pilgrimages to understand how the viewer's sense of time and space is shaped by the use of repetition, duration and montage. The temporal aspect of these visual media, especially the sense of being transported, facilitates Murid visual practices of devotion that are focused on attaining divine unity in this life, or at the very least partaking in the experience of those who are on the path to divine unity such as shaykhs. The importance of Murid websites has not made these visual forms obsolete, in fact, unlike internet viewing, which can be a solitary activity, disciples often watch these videos together, an act that is often facilitated by large screen TVs and stereo speakers. This sense of communality and the spirit of togetherness, solidarity and shared experience, often glossed in the literature as brotherhood, is an important aspect of Murid experience, especially out of Senegal. As I will argue, these videos and DVDs are central to the ways in which Murid women and men construct the religious community through the production, circulation and viewing of visual media. 
Few Murid devotees have the opportunity to see or touch their spiritual masters, especially those who journey abroad and who do not return to Senegal for years for reasons such as financial constraints and an undocumented immigration status. Moreover, exalted Murid figures rarely leave their compounds in the rural town of Tuba and access to them is restricted to high-ranking initiates including Muslim scholars, government and business leaders. ${ }^{\mathrm{v}}$ They are more likely to be heard on the radio or seen in the variety of media circulating in an out of Senegal. The electronic mediation of devotional practices, including videocassette and DVD recordings of annual pilgrimages, produces feelings of nearness to spiritual leaders for disciples in Senegal and abroad. Through a variety of visual practices related to new media devotees receive religious merit and grace that are thought to lead to spiritual and material enrichment and participate in the construction of the moral community.

Murid adepts abroad circulate other Muslim paraphernalia in addition to videocassettes such as audiocassette and audio-CD recordings of sermons and praise singing of religious griots, DVDs of other major pilgrimages and religious conferences, portraits of family members and religious figures, foods, textiles and clothing, and religious texts. In addition to these cultural objects that facilitate Murid devotion, congregants also construct and view websites as members of religious associations called da'ira. Through these diverse media forms, many of which have become more affordable and accessible in Dakar and abroad such as the Internet, overseas Muridiyya connect to life at home, in Senegal, where Islam has gained new visibility in the last decade.

In addition to the emergence and proliferation of Muslim media, in the Senegalese capital of Dakar, the signs of Islam are everywhere. Alongside the stalls of religious paraphernalia, such as prayer beads, mats, head coverings, and religious texts, one may also find talismans produced 
by Murid leatherworkers and artisans bearing photos of the shaykhs, photographs and wall hangings. One may also find mass-produced consumer goods: calendars and clocks with Muslim themes, images of Mecca and those bearing Arabic calligraphy, bumper stickers and key rings for cars and decals for store windows and vending stalls. ${ }^{\text {vi }}$ [Figure 2, Murid themed bumper stickers decorate a basin used to collect donations] Recently however, Chinese development aid to Senegal has been accompanied by Chinese merchants selling Islamic themed housewares and images relevant to Senegalese Muslims including Murid images mass produced in Chinese factories (Roberts 2010:5). ${ }^{\text {vii }}$ Images of Bamba and other major religious figures are wildly popular in Senegal; they grace the walls of homes and shops. In navigating the city one is struck by the prominence of Muslim themes in urban expressive forms such as public murals and graffiti that have transformed secular spaces and places of work into places of piety (Roberts and Roberts 2007; Roberts, et al. 2003:4), and in popular and religious music heard in shops and on public transportation (McLaughlin 1997). Even the modernist rational layout of the city, its grids, boulevards and round points carry the names of Muslim figures and iconography of the Sufi congregations. The signs of Islam index these spaces as Muslim places and their occupants and those who pass through them as potential beneficiaries of grace (baraka). These visual forms and practices mark urban spaces typically thought of as modern and secular with a new Muslim cosmopolitanism (Diouf 2000).

In part Muslim thought and practice have gained heightened visibility through the liberalization of broadcast media such as television and radio, but also through the spread of new technologies such as the Internet, digital recording and broadcasting, facsimile machines and desktop publishing. These new developments have been deeply contested in Senegal by secular and Muslim publics. The terms of public debate in Dakar have come to turn on such matters as 
the increasing visibility of religious affiliations of candidates for public office (Mbow 2008:162), women's sartorial practices, and Muslim media, including the use of radio, television and Internet. Moreover, the liberalization and independence of the print and broadcast media has been hotly debated in Senegal. During the presidency of Abdoulaye Wade independent media have been at odds with the government leading to questions about the freedom of the press in this secular republic (Mbow 2008:163). The proliferation of small media in particular, such as radio broadcasting, have permitted the rise of new religious figures, who may not have the conventional criteria for leadership such as genealogical claims and scholarship, a larger audience (see also Schulz 2006). Religious figures themselves have also come to question the interpenetration of the religious and public, especially with regard to popular cultural practices such as the invocation of Muslim themes in music, films and novels. For example the Mbalax star Youssou N'dour's 2004 album, Egypt (Nonesuch Records), was banned in Senegal for two years after its release; it was not played on the radio and cassettes were withdrawn from the market. At issue in this album was N'dour's combination of African rhythms with the Egyptian arrangements of the Fathy Salama Orchestra in praise of Sufi Islam. As a pop star, N'dour was widely criticized in the Senegalese press for recording religious music and accused of blasphemy. ${ }^{\text {viii }}$ Many of the tensions revolved around N'dour's attempt to film his music video during the annual pilgrimage, known as the Mággal, to Tuba. Mbalax rhythms and dancing are often seen as incompatible with Muslim decorum and restraint.

It is now conventionally accepted that the intertwining of secular and religious forces has led to the relative stability of the Senegalese state in the postcolonial period (Cruise O'Brien 2003; Villalón 1995). Yet how do we understand Islam's new visibility with respect to cultural processes such as the proliferation of Muslim media and consumption practices oriented toward 
the creation of the proper, pious and prosperous body? Clearly the spread of media technologies and liberalization has provided a platform for religious voices destabilizing the association of modernity and modern technologies with the decline of religion (Meyer and Moors 2006; Soares 2004). ${ }^{\text {ix }}$ Technological innovations, global infrastructures, inexpensive media technologies, and state liberalization have facilitated the emergence of a Muslim public sphere, or as Charles Hirschkind (2006) argues, a Muslim counterpublic, indexing the multiplicity of voices and positions occupying these newly mediated spaces that counter the singular authority of the state and the religious hierarchy. Here I wish to focus less on debates and new understandings of Islam fostered by religious media and concentrate on how among Senegalese Murid adepts, electronic media have expanded devotees' repertoire of devotional practices and facilitated their desire for proximity to religious guides. Disciples watch videos and television programming, listen to audio cassettes and the radio, and read the internet and religious texts to learn from renowned scholars and leaders, to benefit from their baraka, an active force in the world, and to render their pious persona visible to others through the act of viewing and being viewed.

Does the appeal of Muslim media challenge the secular republic and attendant notions of the significance of a secular public sphere? Certainly in this age of the U.S. led global War on Terror, Islam seems to be everywhere more visible, or so the argument goes. In places like France and Turkey religious signs and symbols have been outright banned in municipal spaces. Some have countered that these developments represent an "excess of secularism" and that the contemporary concern with secularism is a "fetish of modernity" (Gole 2002:184). In some ways the notion of a Muslim public sphere is not new. Although new modes of communication have fostered new Muslim publics, Muslim thought and practice have had public visibility historically and in many parts of the globe in part through efforts at mass education (Eickelman and 
Anderson 2003:1). As I said above, as the state relinquishes its control over the media, new religious actors have emerged in these newly opened spaces. Yet, visual and aural practices have historically been incorporated into Sufi life in Senegal. Religious leaders have appreciated the utility and symbolic significance of the microphone, telephone, radio, photocopier and camera and employed these technologies to further their mission and address their followers. For example, the supreme leader of the Muridiyya, the Khalife Générale, has historically given an address over the radio at the start of the rainy season to signal the beginning of the planting season for the faithful and on the occasion of the annual Mággal pilgrimage to Tuba (Gueye 2003). Disciples have historically sought proximity to guides through pilgrimage and religious visits known as ziyara, and these practices have been augmented by electronic media, which in some cases have taken the place of physical travel for disciples unable to make the trip.

The appeal of Muslim medias and the publicity of Islam in Senegal are related to the overseas migration of Murid adepts in the context of the recent history of economic volatility. The visual culture of Sufi Islam remains a central motivating force for adepts abroad and has become an important means of participating in life at home. For adepts of the Muridiyya visuality has been at the heart of Murid devotion and has taken on new meaning as adepts search for moral renewal at home and self-transformation through migration and travel, an important theme in Sufi thought. Additionally, media and communications technologies, such as photography, videography, telecenters and Internet cafes, are tied to the movement of Murid followers into the unregulated sectors of the urban economy in the past thirty years. In the context of prolonged economic uncertainty, devotees of the Muridiyya create long-term value through carefully crafted financial strategies including the construction of global trade networks and the expansion into the so called informal sector trade of Dakar and Tuba (Buggenhagen 
2010). The new prominence of Muslim commodities, iconography and visual practices reflects the desire to create long term forms of value in the face of uncertainty (Guyer 2004). It is in this context that I analyze the visual (and aural) culture of religious videocassettes and DVDs. I focus on the global circulation of these visual objects to understand how viewers describe their talismanic properties as protective, healing, and spiritually and materially enriching and how they contribute to the constitution of the moral community (Roberts and Roberts 2000; Starrett 1995).

As much as participating in the annual Mággal pilgrimage to Tuba is considered to offer opportunities for self-transformation, so is the electronic mediation of this genre of religious travel. Attention to cultures of electronic mediation suggests the significance of analyzing visuality as a practice; "Mouride visuality is above all a visuality of practice" (Roberts and Roberts 2000:225). The experience of viewing Mággal videocassettes is described by viewers as transformative; such viewing (and listening) is considered a pious act worthy of merit (Eisenlohr 2006; Hirschkind 2001), a mode of participating in a global Muslim community, and an important source of religious authority and authenticity. Additionally, disciples viewing Mággal videocassettes describe them as transporting; they take the viewer back to Tuba within the realm of the Sufi masters and ultimately the divine. For these reasons, the medium of the videocassette and the practice of viewing and being viewed are central to the production of value for Murid disciples. As visual objects, videocassettes do not merely reflect the community back to its members, the act of viewing them creates a spaciotemporal domain though which the community itself is produced (cf. Munn 1992). Through the practice of viewing and listening to Muslim media women and men at home and abroad strive to create a pious, prosperous and morally correct persona through which they construct their Muslim personhood, the moral community 
and achieve salvation. Disciples often say that the videocassettes of the circulation of wealth during the Mággal pilgrimage are at once the motivation and the outcome of the their hard work abroad and the grace of their founding figure, Amadou Bamba.

\section{Global Circuits of Senegalese Muslims}

The Mággal pilgrimage commemorates the life of the founding figure of the Muridiyya, Amadou Bamba, who was exiled by French colonizers and later kept under house arrest. Much of the Murid visual corpus takes this period of time in Bamba's life as its inspiration. The Muridiyya emerged at the turn of the twentieth century in the context of the collapse of the Wolof kingdoms and the encroaching French colonial presence that opened up Wolof society to a series of messianic movements. During this period of upheaval disciples were attracted to Amadou Bamba, a renowned Muslim scholar. Bamba's biography, Les Bienfaits de l'Eternal, establishes his status as a wali (holy person) by drawing out his genealogical ties and establishing his inheritance of the wird and sufficient baraka (Mbacke 1995). During his life, Bamba demonstrated qualities of divine grace and developed considerable spiritual authority. Bamba's authority stemmed from the recognition of tradition and hierarchy, and also from a divinely inspired message and "the charisma which flowed from it" (Coulon 1985:346). Bamba turned away form violent opposition to French rule and took up cultural forms of resistance (Cruise O'Brien 1975:22; Robinson 1991:150). Bamba attracted disciples from the displaced sectors of the population and he enabled the peasant farmers to escape the oppressive practices of the aristocracy and the warriors who exploited them (Cruise O'Brien 1975:101). Many of Bamba's early disciples were low ranking and thus lacked access to land. Bamba provided his disciples with a practical form of Sufism in which the masses could participate and which the 
colonial worldview could not encompass (Robinson 1991:149). [Figure 3, Picture of Amadou Bamba taken in 1913 by a colonial photographer. (Marty 1917:22)]

The Muridiyya drew the suspicion of French colonial officers. The French feared that Bamba was preparing for an armed jihad to oppose colonial rule because Bamaba had amassed a significant number of gifts from his followers. Additionally, the Wolof aristocracy, fearing the growing following of Bamba and their loss of control over the peasant producers, collaborated with the colonialist to see that Bamba was exiled from Senegal. The French authorities exiled Bamba to Gabon from 1895 to 1902 and to Mauritania from 1903 to 1907 where he became widely recognized among the Qadir way as a master Sufi scholar. Disciples say that Bamba's exile was a reenactment of the hijra or the flight of the Prophet Muhammad from Mecca to Medina in 1/622. Upon Bamba's return to Senegal, he was kept under house arrest in an isolated area of Jolof from 1907 to 1912 . These periods of exile are the source of the miracle corpus that the disciples have constructed around the person of Bamba and contributed to the development of his spiritual legacy.

As I mentioned, Murid visual culture often refers to Bamba's miracle corpus including peinture sous verre, wall hangings, leatherwork and murals placed on compound walls and in urban spaces. As the Muridiyya transformed from an agriculturally based religious movement to urban and overseas trade in the unofficial economy midcentury, I would argue that Murid arts became ever more important for signaling one's membership in this Sufi congregation. More significantly, these religious objects were thought to act as talismans that healed and protected and proffered hoped for prosperity in this life and salvation in the next. They offered a means of remaining connected to the Sufi path and some objects, such as reproductions of images of Bamba, were often used as devotional aids. 
Beginning in the 1960s Murid peasant families began to move way from the rural center of Tuba as world prices for peanuts declined due, in part, to the European Community's end to preferential prices for Senegalese peanut and oil producers in 1968 (Babou 2007a:202; Babou 2007b:202; Gueye 2003). These families were further devastated when, in the 1970s, due to a prolonged period of monocropping, poor environmental management, severe drought, and a series of locust plagues the country experienced a destructive famine. To escape rural devastation and mounting debt many disciples migrated to the urban centers from the central agricultural regions of the country. In Dakar they populated the city with self built dwellings (Creevey 1985:715; Diouf 2000:691; Gueye 2003) and became employed in the burgeoning unregulated sectors of the urban economy (Cruise O'Brien 1988; Diop 1981; Gueye 2003; Roberts 1996:87). At first, Murid agricultural migrants were mere scavengers in the urban areas of Thies and Dakar recycling cleaned up bits of string, bottles, and cans for sale in the market at the religious injunction (ndiggal) of Seriñ Abdoul Lahat Mbacke, the third oldest son of Bamba who inherited the spiritual leadership of the Muridiyya. Over time, Muridiyya transformed the strategy of trading in the dry season to make ends meet in lean agricultural cycles into full-time urban settlement.

Although it might have seemed that urban disciples had moved beyond the rural grasp of their religious guides and that they were in the process of becoming further entrenched in the world market through their trade, "they made a conscious effort to incorporate their unique temporality and rationality into world time by using their own vocabulary, grammar and worldview to understand the world and operate within it" (Diouf 2000:685). In the urban areas disciples congregated into religious associations called da'ira (circle) through which they collected offerings that garnered them an audience with their rural shaykhs and fostered social 
networks that facilitated their entry into the urban economy. Over time as religious associations grew they began to invest in the rural region of Tuba at the behest of shaykhs who came to recognize the importance of these new urban associations. For these disciples Islam became the framework that structured their interactions in the new urban milieu. For example, the patronage of a senior member of the da'ira could enable one to engage in financial transactions within the sphere of that which was morally sanctioned in Islam, thus avoiding riba (interest or increase), which was associated with formal sector economic transactions. The Koran also advises adepts not to sacrifice religious practice for commercial gain in trade, that wealth should be used in the service of God, and that capital obtained through wrongdoing to others is to be avoided (Hunwick 1999:73-74). Moreover, adepts should not participate in gambling or speculation (82). In the capitalist economy, such activities were difficult to avoid; participation in Murid circuits of exchange contributed to the strategies that good Muslims could employ in seeking a living within their moral aspirations and the financial constraints of their time.

Although many Murid families who had been engaged in farming in the peanut basin had picked up for the city, or at least sent a son to labor there on their behalf, others sojourned abroad. A labor shortage in postwar France drew many former colonial subjects abroad to work on docks, in maritime shipping and in factories (Bowen 2004:44). As former colonies gained independence, a multilateral agreement between France and Senegal allowed Senegalese to move without restriction (Diop and Michalak 1996:77). Many Murid disciples immigrated to France in this period in search of university degrees and wage labor, and some became involved in an international trade in African art perhaps inspired in part by the opportunities offered by the 1966 Paris Exposition de l'Art Nègre (Cruise O'Brien 1988:139). By the 1980s, Murid communities had grown in New York, Belgium, and Italy (Diouf 2000). As immigration policies became more 
strict in France, the U.S. Amnesty Law passed in 1986 facilitated a greater circular migration of these traders and disciples as their status was regularized and the numbers of Muridiyya in the United States grew steadily (Babou 2002:160). The 1990 Immigration Act, which introduced the Diversity Immigrant Visa Program that provided permanent resident visas to citizens of countries with low immigration rates to the United States, also contributed to the rising number of Senegalese (Beck 2008:200).

The political economic context of Murid urban and overseas migration is important to understanding the centrality of religious imagery in the Murid spiritual economy. These images connect overseas locales to the spiritual center of Tuba. For example, in the late 1990s the Murid religious association in Chicago not only hyphenated its name, Da'ira Tuba-Chicago, to indicate its connection to Tuba, but also adorned their meeting space in an apartment in the Rogers Park neighborhood with Arabic calligraphy on the wall that read "jerejef Amadou Bamba" or "thank you Ahmadou Bamba" and hung portraits crafted by Murid artisans of Bamba and the Khalifa Générale at the time, Seriñ Salou Mbacke. In a 2005 commemoration of Amadou Bamba in New York City, disciples displayed large billboards with images of male and female shaykhs that stood at the end of the parade route. [Figure 4, Images of Murid female shayhks displayed in New York city in August 2005].

In part Islam's success in the public sphere is related to the success of the Muridiyya in international trade. As economic recession took hold in Senegal, due in part to the decline of agriculture and manufacturing, but also to that fact that the state was unable to derive revenue from the thriving import trade in contraband (Thioub, et al. 1998:71), Murid businesses based on import/export seemed to be thriving. Although the implementation of Structural Adjustment plans mandated by the International Monetary Fund in exchange for loans from the World Bank 
beginning in 1985, and economic and political liberalization in the 1990s was intended to squeeze out these informal markets, Muridiyya continued to profit by working at the interstices of the official and unofficial economy (Hibou 1999:80). As the prospects of the state declined as international financial institutions sought to increase transparency and reduce graft by decreasing the amounts of development aid and loans that filtered through the state, government bureaucrats came to depend largely upon Murid traders who operated abroad to survive.

Although the forms of work in which Murid disciples engaged became less visible as they began trading and moved abroad, the products of their labor in what they could build or buy became central to their moral standing at home. Many in the urban community turned to the signs of Islam to index a new prosperity for some and moral renewal for others. Many devotees had suffered the stigmatism of race abroad and for them Islam at home held a sort of nationalist appeal for men and women alike. Murid men at home sought moral renewal through patronage of Murid shaykhs at a time when the conventional forms of male value were untenable, such as control over land, labor and brides. In Dakar, Murid merchants controlled major markets throughout the latter half of the decade in into the 2000s including the largest cloth market, Marché H.L.M. (Habitations Loyers Modérés) (Mustafa 1998) as well as Marché Sandaga, the largest urban market in Senegal which also serves as a gateway to hundreds of smaller markets throughout the city and its periphery (Diouf 2000:692). As I mentioned however, Chinese merchants who largely populate the Centenaire neighborhood of Dakar, are producing stiff competition for Murid entrepreneurs unable to compete with cheap prices (Roberts 2010).

\section{The Circulation of Religious Media in and out of Senegal}


Murid faithful have expressed their mission through the use of desktop publishing, photocopiers, Internet and photo studios to produce and distribute religious texts and images, through the production and circulation of audiocassette sermons and through radio addresses. Video recordings are part of a larger religious economy of images, especially of religious figures (Roberts and Roberts 1998; 2000). More recently, devotees have turned to videocassettes, DVDs and the Internet where religious associations host websites, post videos on YouTube and Google Video and participate in social networking sites. For Murid disciples and clergy, these new spaces are new territories to be conquered (Gueye 2003).

In the decade after independence the state had a monopoly over broadcast and print media. Television was introduced in the 1960s following independence to a largely urban population and it consisted of francophone programming for the most part (Fair 2003). Unlike other West African countries that liberalized their media in the 1990s such as Mali (Schulz 2006; Soares 2005; Soares 2007), Senegal began to liberalize its print media as early as 1974, though the government still has a monopoly on nationwide television stations through Radiodiffusion Television Sénégalaise (RTS). State television stations RTS1 and RTS2 recognize the appeal of religious programming and thus often broadcast Muslim conferences, pilgrimages, and speeches as well as Muslim themed entertainment such as question and answer programs aimed at providing guidance for a straight life. New private television stations are emerging including Walf $T V, 2 S t v$ and $R d v$ among others, but they are only available in the capital, Dakar. Attempts have been made to launch a Murid television station in Tuba but the state has not yet granted a broadcast license (Gueye 2003). New commercial and community radio stations emerged in the 1990s and among them were the myriad of stations addressing Muslim themes and audiences. Muslim groups broadcast programs through both private and official media channels. There are 
radio stations that are officially Muslim such as Radio Al Hamdoulilah, and those that carry Murid names such as Radio Dunyaa, Radio Touba Hizbut Tarquiyyah, Lamp Fall FM Dakar and Touba.

Men and women can often be found listening to audiocassettes and audio-CDs of religious sermons at home, at work and in their cars or on forms of public transport. The viewing of videocassettes and DVDs of sermons and television broadcasts takes place in many homes that have televisions. Through these aural and visual practices, which include the use of images as devotional aids, disciples benefit from the baraka of the shaykh, receive religious merit from God, and receive guidance for a morally upright and meaningful life. Through aural, visual and corporeal practices related to videocassettes of religious events disciples seek proximity with their shaykhs (cf Pinney 2002). There is mutuality in viewing the video; shaykhs and commentators speak to their viewing disciples and disciples often speak back to the screen. These electronic forms mediate the visceral experience of piety valued by Murid men and women. When watching or listening to these programs disciples often sit on prayer mats, work prayer beads, sway their bodies to and fro, and add commentary in Wolof and Arabic such as bisimilahi (thanks to God), bilay (truthfully) and wow wow (yes).

The desire and appreciation of mediation as facilitating proper practice and proximity to the divine distinguish Murid adepts from other Sunni Muslims. These cassettes are new forms of mediation, which facilitate the relations of the devotee and to the divine, like the figure of the Sufi shaykh (cf Eisenlohr 2006:240). Some disciples say that the practice of viewing these mediated forms is an act of devotion worthy of merit that is augmented with each repetition, much like dhikr practices where disciples chant the litanies of the order. ${ }^{\mathrm{x}}$ These recordings amplify one's prospects for salvation because they are supplementary to required religious 
practice. Although families and groups of neighbors or friends listen intently to such broadcasts, especially on their first airing, at other times these video and audio cassettes may become a backdrop for conversations and gatherings much like a portrait of a shaykh hangs on the wall gracing the space with its presence and endowing the bearer with a righteous persona. The religious videos are often part of a wider collection of frequently viewed media including videos of life cycle ceremonies, video and print photo albums, and music videos (cf Buckley 2000; Mustafa 2002).

Religious media have come to play an increasingly important role for overseas disciples. Disciples abroad seek out these media forms to feel connected to happenings in Senegal. The formal properties of the electronic media reduce spatial and temporal distance between a disciple and a shaykh, between overseas locales and Tuba, and between the here and the hereafter. In addition to circulating recordings, the Muridiyya broadcast their annual pilgrimage to the sacred city of Tuba over the national television station, $R T S$, and unofficial copies of these productions are available in the market. Though this is a recording of a pilgrimage to a rural center, it is often watched and experienced in urban areas, in Dakar and in cities abroad where Murid faithful reside.

\section{Mággal Videocassettes and DVDs}

In the 1990s and into the 2000s video productions of the Mággal often began with still images of Bamba with the minaret of the mosque in Tuba, known as Lamp Fall, superimposed on his robe [Figure 5]. This is a common theme in Murid photography as figure 6 shows; young shaykhs often try to replicate these poses [Figure 6]. This image of Bamba was often followed by a still shot of an image of the current Khalifa Général (successor or caliph) next to the minaret 
[Figure 7]. Many of the video productions followed these scenes with images of thousands of male and female aspirants of all ages crowding into Tuba's main streets, which radiate out from the Grand Mosque at the center of the town. Many of the male and female disciples appeared to be dressed in new, stiffly starched Muslim boubous made of locally dyed brocade cloth known as bazin riche. Yet there were also many others, mainly young men, dressed in jeans and t-shirts. Most of the productions included images of the rural roads jammed with buses, car rapide minivans, and taxis that were meant for urban transport. In some scenes, as far as the eye could see there would be Ndiaga Ndiaye minibuses intended for urban-rural commutes, the airconditioned buses of the late Cheikh Mortalla Mbacke, as well as double axle dump trucks with their trailers spilling over with disciples. RTS productions in the 1990 s frequently captured iconic nationalist images of the Baobab tree juxtaposed with a train headed for Tuba, its boxcars overflowing with Murid disciples from the rural agricultural communes surrounding Tuba. As the train no longer connects Tuba to Dakar, a 2004 production added scenes of aspirants boarding planes and images of planes taking off from airports. [Fig. 8] Voiceovers often explained that these disciples came from all over Senegal - indeed from all over the world - and that they were returning to Tuba to thank their wali (holy person), Amadou Bamba, the founding figure of the Muridiyya. [Fig. 9 A 2004 videocassette of the Mággal]

These videos also included scenes of the mosque in Tuba where cameras would show the work of Sëriñ Saliou Mbacke, the late Khalifa Général (successor or caliph) of the Muridiyya. The most symbolic of his numerous public works projects in Tuba was the gold leaf that he added to the mausoleum of Amadou Bamba along with a crystal chandelier. The cameras often depicted images of male and female disciples tossing coins, banknotes, and kola nuts over the brass railing that separates them from Bamba's tomb as they pray for good health, employment, 
fertility, and the like. In fact, these were often the most repeated scenes in many of these recordings. [Fig. 10 Female disciples praying around Bamba's tomb]

Another common event in the recordings was the visits to the Murid clergy by representatives of the Senegalese state and other political and military figures from African and Middle Eastern countries and France. In these scenes disciples were able to see their spiritual leaders, especially images of the Khalifa Général. Murid elite were often seated on beds or in chairs with their spokespersons seated below them. Their spokespersons guard access to their masters, allowing visitors to briefly kiss the hand of the shaykh one by one in rapid succession. Some Murid shaykhs were seated behind a railing or a metal grill beyond which disciples do not pass. In some productions there is a long pause as the recording focuses on the figure of the shaykh as though a photograph was being taken or inserted into the video.

Many of the recordings include a scene in the Murid library in Tuba where Bamba's manuscripts are archived. A 1996 videocassette included an interview with the custodian of the Murid library at Tuba. The custodian showed the library's stacks and reading room and described the holdings as consisting of writings by key Muslim figures in Arabic as well as French. The custodian also discussed the corpus of writing produced by Bamba himself. A common scene in several recordings was the display cases in the library containing the personal items that belonged to Bamba including his bed and his suitcase and the large framed photo of Bamba that stands in the library over six feet tall. In a 1996 video the custodian of the library completed the tour with a discussion of the jikkoju baax (pious comportment) of a good Murid and of a good Muslim. He emphasized the importance of offerings (hadîya) supplicated to a shaykh. These offerings, he said, signify submission to a Sufi master and the prospect of achieving salvation. He described how money held in one's hand has no value (njariñ), but once 
put into circulation through offerings to a shaykh, the money would acquire njariñ and the disciple would benefit from the shaykh's baraka.

This visit to the library was often followed by images of the offerings of prominent religious associations (da'ira) of men and women devoted to the shaykhs in Tuba, in urban cities in Senegal and abroad. In Senegal there are many da'ira associations that are composed of professionals, bureaucrats, and students; however, it is the contributions of the overseas disciples who sell their wares on the streets of major Western cities that are the focus of many of these video productions. These translocal organizations send yearly offerings to the Murid clergy from places such as Milan, Paris, New York, Chicago, and Washingto n, D.C. Not only do they send cash, but they also send crates of goods to promote public hygiene during the pilgrimage such as bleach and ammonia. The videos also documented the clinics (and a hospital), sewage systems, port-o-potties, and rural electrification projects made possible by the liggéey (work) of disciples abroad. In fact, the videos often contained scenes of an electrified Tuba shot at night with a carnivalesque atmosphere of young people, grilled meats and much visiting. Other important shots also included the massive offerings of food. There were scenes of livestock, grains and water offered by da'ira associations as well as cooked food being offered to the shaykhs and redistributed to the faithful.

What was not captured in these videos were the profane aspects of the city of Tuba, located on its outskirts. There were no shots of the Arrondissement de Ndame, where Tuba is located including the local gendarme or the compound of the prefect. Absent as well are images of the large market, Marché Ocass, which many disciples make a point of visiting during their pilgrimage and the garbage dumps on the edges of the town. 
In these broadcasts the camera often shifted back and forth between these scenes and repeating images of religious singing (dhikr) by accomplished Murid griots, men and women crowding around Bamba's tomb (in gender segregated groups) and throwing offerings over the railing surrounding it, of the prayerful masses filling the streets, and long lines of dignitaries greeting the shaykhs. Another common cut scene might include aerial shots of Tuba most likely taken from one of the minarets of the mosque in which one can see the radial plan of the streets of Tuba emanating from the mosque and view the crowd below. [Fig. 11]

These screen images concretize a vast circulation of prestations underpinning translocal circuits of wage labor and capital organized under the aegis of the Muridiyya. The recordings are the condensation of the forms of wealth that circulate on the day of pilgrimage - food, money, and transport - and give evidence of both the work of the disciples abroad and as disciples often say, the magnitude of the shaykh's blessings, all of which are made possible by the grace of God. These videos can be found in the parlors of homes in and out of Senegal, under television cabinets in rooms decorated by the portraits of religious figures and iconography of religious devotion such as Muslim calendars, wall clocks and framed scripture.

\section{Repetition, Duration, and Montage}

Murid video practices, like other Murid arts such as painting, leatherwork and photography, emphasizes the image of Bamba. The image of Bamba upon which Murid visual culture builds was taken by French colonial officers who employed photography to document the activities of Muslim shaykhs whom they suspected of fomenting resistance to colonial authority. The French only snapped one photograph of Bamba and its singularity over time became the basis of its reproduction as a devotional image. Allen and Mary Nooter Roberts have analyzed 
how the colonial photograph of Amadou Bamba has been incorporated into Murid devotional and artistic practices (Roberts and Roberts 1998; 2000; Roberts, et al. 2003:76). They argue that these images of the wali have a presence that "gets things done...they are endowed with baraka" (Roberts, et al. 2003:76). The Roberts' (2000) argue that there is also a particularly Sufi way of seeing religious images that understands these objects as generative of something else. For Murid adepts in particular who often hold or sit in front of images during devotional practices including dhikr, who touch these photos and then their heart, the seat of Sufi knowledge, baraka is sought through visual imagery and practices (Roberts and Roberts 2007:56). Although Murid disciples do not seem to use the Mággal videocassettes to aid in their practice of $d h i k r$, as they do with the images of Bamba, pilgrimage videos are an important means through which one accrues baraka, divine merit, and participates in and produces the Muridiyya through the act of viewing, even if from afar. Moreover, watching videos and DVDs of the Mággal clearly seemed to fill Murid adepts with pride and dignity; viewers often pointed out to me how the shaykhs provided for them during the scenes capturing the distribution of bowls of millet and meat and of the forms of infrastructure the disciples' remittances to Tuba had built.

Not only do the videocassettes and DVDs show images of the original photograph of Bamba, as well as works of art that have been developed around this photograph, the recordings show images of exalted leaders of the Murid order, which may be as close as many followers ever come to seeing their faces. Importantly, as I mentioned, when these images of shaykhs are shown the camera tends to linger on the image, all action stops and stillness endures as though the time and temporality of this world has been transcended. This manipulation of time through the technique of duration is an important element of the video production. It creates a spaciotemporal domain in which disciples and guides can dwell simultaneously in and out of time. 
In the videos one sees the forms of value that animate Murid efforts abroad such as homes, mosques, schools and clinics for example. The videos index the economic power of the Muridiyya and the baraka of the shaykhs by rendering the circulation of wealth visible. As I described above, one is presented with images of offerings of cash, food and livestock, development projects of the overseas da'ira associations, and throngs of believers. Importantly, the recording also attests to the shaykhs' redistribution of these forms of wealth. The viewer sees the shaykhs re-distributing bowls of rice and meat that the da'ira associations prepared for example. The wealth that circulates in the broadcasts, videocassettes, and DVDs are recognized as being not only signs of the baraka of the Murid shaykhs, but also as containing the elements that produce the social system, that is, the Muridiyya itself.

These images are repeated throughout the production. In fact, in some video productions, the exact same scene is repeated throughout. The use of repetition in the video resonates with the practice of dhikr and its emphasis on repetition (Roberts and Roberts 2007:57). As I described, the viewer is presented with alternating images of dhikr chanting and wealth in disciples, offerings and infrastructure. Repetition has a certain multiplier effect in this case amplifying opportunities for the viewer to receive grace that disciples say has the potential to lead to spiritual and material well being (Roberts and Roberts 2007:67).

As I mentioned once the viewer of the video is taken into the Murid library and presented with a discussion of the significance of the hadîya offerings, the camera then returns to images that were shown previously: the masses of pilgrims arriving in boxcars, to those waiting in line to enter the mausoleums, to those performing ziyara (religious visits) to living guides, and of dhikr chanting and again to the offerings and redistribution of those offerings. Like the Gambian studio photographers described by Liam Buckley, it would seem that Murid videographers also 
seek to "multiply surfaces" to produce multiple views, and thus meanings, by cutting the images into montages (2000:1). Thus the video works much like photographs of Murid shaykhs traded in the market in which montage is a popular way of manipulating images. For example, one can often find a photograph in which all of the Murid shaykhs appear with Bamba as though they exist at the same time and simultaneously out of time. (Fig. 12: Photograph traded in the market in 2000). Montage also can facilitate the feeling that one has entered into the frame and create visual relationships between images as they are placed in proximity to one another (Roberts and Roberts 2007:63). These videos, as a form of montage, disclose visual evidence of hard work and grace; they also intimate the desire to impart the tactile manifestations of grace on others. As wealth objects and representations of wealth videocassettes have a "density" (Weiner 2001:308), "features of the image are not only found meaningful, they may do something" (Roberts, et al. 2003:48).

An important reason that the Mággal videos emphasize the offerings and their redistribution in the form of the development of Tuba is that the annual pilgrimage is an important time during which disciples endeavor to travel to or return to Tuba to renew their vow of submission to their spiritual leaders through offerings. If the disciple is fortunate, she or he may catch a glimpse of exalted figures of the Muridiyya, if she or he has been initiated to a lesser religious figure then the hope is to have the opportunity to deliver the gift in person, to be touched by a shaykh, and to receive baraka. What is the relation then between how images of the Mággal pilgrimage look, with the use of duration, repetition and montage, and why they work (Roberts, et al. 2003:22)? To understand this social process begins with acknowledging that the meaning of these images is never fixed. The relationship between "discursive formations and image worlds" is ever shifting allowing for the "transformational potentialities" (Pinney and 
Peterson 2003:3) and "volatility" (ibid 6) of photographic and videographic practices. As a form of visual and aural communication the video is also part of the repertoire of social labor that goes into rendering hadîya offerings meaningful. These meanings are produced in part through talk about the significance of the offering in the video, thus setting offerings aside from the mundane temporal world of work. Framing the offerings of money in the language of Islam and salvation is important because an offering of money is an object and, like any other object, it is susceptible to different readings. The money form in particular can be characterized by its indeterminacy and openness (Maurer 2006:17). Thus the representational quality of money is often fixed through talk; "objects require the reflexive capacity of language if they are to serve as fully efficacious media of social relations... the capacity of objects to serve semiotically as representations and economically as representatives of persons is unstable and requires constant effort to sustain" (Keane 2001:74). When cash is given to a shaykh through the institution of hadîya offerings as represented in the video it is no longer an alienable commodity, a standard of value, or a symbol of the state. Instead, it signifies both submission in this world and the next to the path to divine union and also the recognition of the shaykh as a worthy guide.

In addition to producing religious value, through viewing the video the overseas disciples constitute a mode of spacetime (Munn 1992:9) that connects them to shaykhs in Tuba. Through practices of supplication and travel represented in the video recording both the overseas labor migration and the return for the annual pilgrimage, the Mággal video creates a spaciotemporal domain apart from the mundane in which the disciple and the shaykh are connected through the act of viewing and being viewed. Through the act of viewing, the disciples seek to extend themselves, beyond their immediate person, in both space and in time, between the temporality 
of this world and eternity, between their locations outside of Senegal and Tuba. Importantly, they hope to be viewed by others as participating in this spiritual act of devotion.

The vocation of the Sufi disciple is, through various practices, to reach toward divine union, in this life. In Sufi thought, travel is the idiom used to describe the means of achieving divine union, to be a Sufi is to be a traveler. For Murid disciples travel is the extension of the self in both space and time. Not only do they articulate travel as a means of participating in the experience of Amadou Bamba who as I mentioned was exiled by the colonial authorities, they also regard travel as an opportunity for gaining knowledge and enlightenment. For Murid men and women, travel may take them further from their life in Senegal, but it brings them closer to their spiritual master, not only Bamba, but also their present day shaykhs in Tuba, and thus, closer to God. It is not just that these practices occur in or through time and space, "they constitute the spacetime in which they go on" (Munn 1983:280).

Importantly, the Mággal video is a production about return to Tuba, the rural heartland of the Muridiyya that has emerged as a "spiritual metropolis" (Ross 1995; Ross 2006) in the late $20^{\text {th }}$ century due to the influx of commodities and cash from Murid traders abroad. Tuba's very existence has always been dependent upon its connection to globalized economic processes: first through the export of peanuts to France, and then, following ecological and economic crises in the last three decades, through trade in diverse commodities across North America, Europe, and also the Middle East. Unlike the ad hoc growth of other African cities, Tuba's rationalized development is iconic of the Murid view of their role in the global economy. It proceeds both from the Murid clergy's control over circuits of production and exchange, at local, national and transnational levels, and from their disciples' submission to this authority through their offerings to the shaykhs in cash or kind. 
Tuba is not just a representation of paradise, it is how disciples access to paradise; "as a semiotic construct, Tuba expresses eschatological desire-the desire for access to eternal prosperity" (Ross 1995:223). In Sufi thought, Tuba is the name of the Tree of Paradise. It marks the realm between the divine and the realm accessible to aspirants; "Tuba grows in paradise where its fruits nourish the righteous and rivers gush forth and beneath its ample shade" (Qur'an 56:27-34). The mosque lies at the point of origin of both space and time as it has been constructed on the site of Bamba's first revelation and contains within it the sundial that orients the adherents to its time (Ross 1995:226). The images presented to the viewer in the Mággal recordings not only index a spiritual world, but also are the very means of its constitution and the authority of those who rule over it. Likewise, the recordings of the return to Tuba indexes Tuba as the fulcrum of heaven and earth and the disciple viewing it as worthy of salvation.

\section{Conclusion}

The electronic mediation of devotional practices, such as the Mággal pilgrimage in Senegal, facilitate the sense of nearness that many adepts of the Murid Sufi way seek with their spiritual masters. Through a variety of visual practices devotees receive religious merit and grace that are thought to lead to spiritual and material enrichment and construct the moral community. Media productions such as the Mággal video are central to the Murid spiritual economy in which offerings are made and redistributed to the faithful. The video production plays a central role in the creation of value by Murid disciples by making visible, and thus meaningful, the workers' investment in Tuba. This visual evidence of hard work is important because the majority of this work takes place outside of Tuba, in the unregulated spaces of the urban Dakar economy and abroad in major Western cities. 
The heightened visibility of Islam in Dakar has been facilitated by access to media technologies and state liberalization of broadcast media. Muslim media practices in urban Dakar challenge the association of modernity with the decline of religion. In part Islam's new visibility is also related to the success of the Muridiyya in international trade. Although the forms of work in which Muridiyya engaged became less visible as they began trading and moved abroad, the products of their labor in what they could build or buy became central to their moral standing at home. Murid disciples create long-term value in contexts of global volatility through the production and circulation of valued objects such as religious paraphernalia. Muslim media practices, such as the viewing of audiocassettes, are central to the creation of the proper, pious and prosperous body in times of moral and fiscal uncertainty.

\section{Acknowledgements}

My sincere thanks to the anonymous reviewers of Visual Anthropology Review for the valuable comments and suggestions. Portions of this research and writing were supported by a grant from the Wenner Gren Foundation, a Summer Stipend from the National Endowment for the Humanities and a fellowship from the College Arts and Humanities Institute at Indiana University. 


\section{Figures}

Figure 1 Murid owned shops in Harlem, New York City, 2005.

Figure 2 Murid themed decals in Tuba, Senegal, 2000.

Figure 3 Picture of Amadou Bamba taken in 1913.

Figure 4 Billboard showing female shaykhs of the Muridiyya, Harlem, New York City, 2005.

Figure 5 Screenshot of image of Amadou Bamba from a 2004 Mággal videocassette.

Figure 6 Young shaykh in Tuba, 2000.

Figure 7 Screenshot of image of Khalifa General next to Lamp Fall from 2004 Mággal videocassette.

Figure 8 Screenshot of image of disciples boarding a plane from 2004 Mággal videocassette.

Figure 9 Cover of a 2004 Mággal videocassette.

Figure 10 Screenshot of disciples praying at Amadou Bamba’s tomb from 2004 Mággal videocassette.

Figure 11 Aerial shot of Tuba mosque from 2004 Mággal videocassette.

Figure 12 Image of Murid shaykhs exchanged in the markets in Senegal, 2000. 


\section{References}

Babou, Cheikh Anta

2002 Brotherhood Solidarity, Education and Migration: The Role of the Dahiras

Among the Murid Muslim Community of New York. African Affairs 101:151-70.

2007a Fighting the Greater Jihad. Amadu Bamba and the Founding of the Muridiyya of Senegal, 1853-1913. Athens: Ohio University Press.

2007b Urbanizing Mystical Islam: Making Murid Space in the Cities of Senegal. International Journal of African Historical Studies 40(2):197-223.

Beck, Linda

2008 Brokering Democracy in Africa: The Rise of a Clientelist Democracy in Senegal. New York: Palgrave.

Bowen, John

2004 Does French Islam Have Borders? Dilemmas of Domestication in a Global Religious Field. American Anthropologist 106(1):43-55.

Buckley, Liam Mark

2000 Self and Accessory in Gambian Studio Photography. Los Angeles: Visual

Anthropology Review.

Buggenhagen, Beth

2010 Hard Work, Hard Times: Global Volatilities and African Subjectivities. In Killer Bargain: The Global Networks of Senegalese Muslims and Policing Unofficial

Economies in the War on Terror. A.-M. Makhulu, B. Buggenhagen, and S. Jackson, eds. Berkely: University of California.

Burckhardt, Titus

1995 An Introduction to Sufism. D.M. Matheson, transl. London: Thorsons.

Creevey, Lucy

1985 Muslim Brotherhoods and Politics in Senegal in 1985. The Journal of Modern African Studies 23(4):715-21.

Cruise O'Brien, Donal B.

1975 Saints and Politicians. Essays in the Organization of a Senegalese Peasant

Society. Cambridge: Cambridge University Press.

1988 Charisma Comes to Town. Mouride Urbanization, 1945-86. In Charisma and Brotherhood in African Islam. C. Coulon and D.B. Cruise O'Brien, eds. Pp. 135-56. Oxford: Clarendon Press.

2003 Symbolic Confrontations: Muslims Imagining the State in Africa. New York: Palgrave.

Diop, Momar Couba

1981 Fonctions et activités des dahira Mourides urbains (Sénégal). Cahiers d'études africains XX(1-3):79-91.

Diop, Mustapha, and Laurence Michalak 
1996 'Refuge' and 'Prison': Islam, Ethnicity and the Adaptation of Space in Workers' Housing in France. In Making Muslim Space in North America and Europe. B.D. Metcalf, ed. Pp. xix, 264 p. Berkeley: University of California Press.

Diouf, Mamadou

2000 The Senegalese Murid Trade Diaspora and the Making of a Vernacular Cosmopolitanism. Public Culture 12(3):679-702.

Eickelman, Dale F., and Jon W. Anderson

2003 New Media in the Muslim World : The Emerging Public Sphere. Bloomington, Ind.: Indiana University Press.

Eisenlohr, Patrick 2006 As Makkah is Sweet and Beloved, So is Madina: Islam, Devotional Genres and Electronic Mediation in Mauritius. American Ethnologist 33(2):230-245.

Fair, Jo Ellen

2003 Francophonie and the National Airwaves: A History of Television in Senegal. In Planet TV: a global television reader. L. Parks, ed. Pp. 189-210. New York: New York University Press.

Gole, Nilufer

2002 Islam in Public: New Visibilities and New Imaginaires. Public Cult. 14(1):173190.

Gueye, Cheikh

2003 New Information and Communications Technology Use by Muslim Mourides in Senegal. Review of African Political Economy 98:609-625.

Guyer, Jane I.

2004 Marginal Gains: Monetary Transactions in Atlantic Africa. Chicago: University of Chicago Press.

Hibou, Béatrice

1999 The 'Social Capital' of the State as an Agent of Deception. In The Criminalization of the State in Africa. J.-F. Bayart, S. Ellis, and B. Hibou, eds. Pp. 69-113. Bloomington: Indiaa University Press.

Hirschkind, Charles

2001 The Ethics of Listening: Cassette-Sermon Audition in Contemporary Egypt. American Ethnologist 28(3):623-649.

2006 Cassette Ethics: Public Piety and Popular Media in Egypt. In Religion, Media and the Public Sphere. B. Meyer and A. Moors, eds. Pp. 29-51. Bloomington: Indiana University Press.

Hunwick, J.O.

1999 Islamic Financial Institutions: Theoretical Structures and Aspects of their Application in Sub-Saharan Africa. In Credit, Currencies and Culture. African Financial Institutions in Historical Perspective. E. Stiansen and J.I. Guyer, eds. Pp. 72-96. Stockholm: Nordiska Afrikainstitutet.

Kane, Ousmane 2009 Les marabouts senegalais et leur clientele aux Etats-Unis. Afrique contemporaine 3(231):209-228.

Keane, Webb 
2001 Money is No Object: Materiality, Desire and Modernity in an Indonesian Society. In The Empire of Things: Regimes of Value and Material Culture. F.R. Meyers, ed. Pp. 65-90. Santa Fe: School of American Research Press.

Lings, Martin

1993 What Is Sufism? Cambridge: Islamic Texts Society.

Marty, Paul

1917 Études sur l'Islam au Sénégal. Two vols. Paris: Maison Ernest Leroux.

Maurer, Bill

2006 The Anthropology of Money. Annual Review of Anthropology 35:15-36.

Mbacke, Serigne Bachir

1995 Les bienfaits de l'eternel ou la biographie de Cheikh Ahmadou Bamba M'Backe. K. Mbacke, transl. Dakar: IFAN.

Mbow, Penda

2008 Senegal: The Return of Personalism. Journal of Democracy 19(1):156-69.

McLaughlin, Fiona

1997 Islam and Popular Music in Senegal: The Emergence of a "New Tradition".

Africa 67(4):560-581.

Meyer, Birgit, and Annelies Moors

2006 Religion, Media, and the Public Sphere. Bloomington: Indiana University Press.

Munn, Nancy D.

1992 The Fame of Gawa: A Symbolic Study of Value Transformation in a Massim

(Papua New Guinea) Society. Durham: Duke University Press.

Mustafa, Huda Nura

1998 Practicing Beauty: Crisis, Value and the Challenge of Self-Mastery in Dakar

1970-1994, Harvard University.

2002 Portraits of Modernity: Fashioning Selves in Dakarois Popular Photography. In

Images and Empires: Visuality in Colonial and Postcolonial Africa. D.D.K. Paul Stuart

Landau, ed. Berkeley: University of California Press.

Pinney, Christopher

2002 The Indian Work of Art in the Age of Mechanical Reproduction. In Media

Worlds: Anthropology on a New Terrain. F. Ginsburg, L. Abu-Lughod, and B. Larkin, eds. Pp. 355-369. Berkeley: University of California Press.

Pinney, Christopher, and Nicolas Peterson

2003 Photography's Other Histories. Durham: Duke University Press.

Roberts, Allen F.

1996 The Ironies of System D. In Recycled, Re-seen: Folk Art from the Global Scrap

Heap. C. Cerny and S. Seriff, eds. New York: Harry Abrams for the Museum of International Folk Art Santa Fe.

2010 Recolonization of an African Visual Economy. African Arts 43(1):1-8.

Roberts, Allen F., and Mary Nooter Roberts

1998 L'Aura d'Amadou Bamba: Photographie et fabulation dans le Senegal urbain. Anthropologie et Sociétés 22(1):15-40. 
2000 Displaying Secrets. Visual Piety in Senegal. In Visuality Before and Beyond the Renaissance. Seeing as Other Saw. . R.S. Nelson, ed. Cambridge: Cambridge University Press.

2007 Mystical Graffiti and the Refabulation of Dakar. Africa Today 54(2):51-77.

2008 Flickering Images, Floating Signifiers: Optical Innovation and Visual Piety in Senegal. Material Religion 4(1):4-31.

Roberts, Allen F., et al.

2003 A Saint in the City : Sufi Arts of Urban Senegal. Los Angeles, Calif.: UCLA

Fowler Museum of Cultural History.

Robinson, David

1991 Beyond Resistance and Collaboration: Amadu Bamba and the Murids of Senegal. Journal of Religion in Africa 21(2):149-69.

Ross, Eric

1995 Tuba: A Spiritual Metropolis in the Modern World. Canadian Journal of African Studies 29(2):222-259.

2006 Sufi City. Urban Design and Archetypes in Touba. Rochester: Univeristy of Rochester Press.

Schulz, Dorothea E.

2006 Morality, Community, Publicness: Shifting Terms of Public Debate in Mali. In

Religion, Media and the Public Sphere. B. Meyer and A. Moors, eds. Bloomington:

Indiana University Press.

Soares, Benjamin F.

2004 Muslim Saints in the Age of Neoliberalism. In Producing African Futures: Ritual and Reproduction in a Neoliberal Age. B. Weiss, ed. Pp. 79-105. Leiden: Brill.

2005 Islam in Mali in the Neoliberal Era. African Affairs 105(418):77-95.

2007 Rethinking Islam and Muslim Societies in Africa. African Affairs 106(423):31926.

Starrett, Gregory

1995 The Political Economy of Religious Commodities in Cairo. American Anthropologist 97(1):51-68.

Thioub, Ibrahima, Momar Coumba Diop, and Catherine Boone 1998 Economic Liberalization in Senegal: Shifting Politics of Indigenous Business Interests. African Studies Review 41(2):63-89.

Villalón, Leonardo A.

1995 Islamic Society and State Power in Senegala. Cambridge: Cambridge University Press.

Weiner, Annette B.

2001 A Conversation with Annette Weiner. In The Empire of Things: Regimes of Value and Material Culture. F.R. Myers, ed. Sante Fe: School of American Research.

\section{Notes}




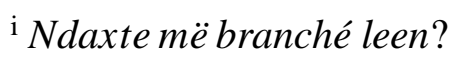

ii Sufism is the esoteric or inward (batin) aspect of Islamic practice that involves direct contemplation of "divine realities" and its transmission from one master to another Burckhardt, Titus

1995 An Introduction to Sufism. D.M. Matheson, transl. London: Thorsons. P. 15. iii In Arabic tariqa is synonymous with sirat, or path, but it has a wider meaning and can be translated as ways and means Lings, Martin

1993 What Is Sufism? Cambridge: Islamic Texts Society. P. 28.

iv See for example the excellent work by Nesper, E. (2008). Digital Disciples, Virtual Piety, and Mediated Knowledge: The Murid Migration into Cyberspace. Masters Thesis in African Studies. University of California, Los Angeles.

${ }^{v}$ Although Murid leaders are rarely accessible to their disciples, this is not the case of lesser figures who have been known to visit their disciples in urban areas and overseas to build their base of followers and bolster their position with respect to the centralized religious hierarchy, see Kane, Ousmane

2009 Les marabouts senegalais et leur clientele aux Etats-Unis. Afrique contemporaine 3(231):209-228.

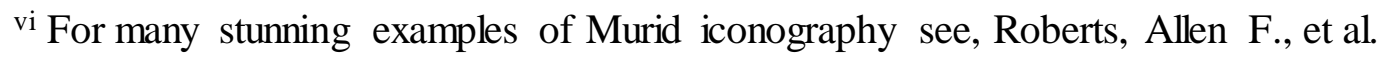

2003 A Saint in the City : Sufi Arts of Urban Senegal. Los Angeles, Calif: UCLA Fowler Museum of Cultural History. vii My thanks to the anonymous reviewer who recommended Allen Roberts" "first word" in the Spring 2010 volume of African Arts in which he observes that the presence not only of Chinese produced Murid images in the local economy but of all Chinese consumer goods has been deeply 
contested in Senegal.

viii In 2008 a film was released concerning this controversy, I Bring What I Love, directed by Elizabeth Chai Vasarhelyi. For a discussion of this controversy see 'Youssou N'Dour Film Explores Music and Islam,” by Edith Honan, http://www.reuters.com/article/idUSTRE55F6XW20090616, accessed 3/17/2010, and "I Bring What I Love-Youssou Ndour: Ce Film me rend fier!,” http://www.seneweb.com/news/article/23561.php, accessed on 3/17/2010.

ix See Meyer, Birgit, and Annelies Moors 2006 Religion, Media, and the Public Sphere. Bloomington: Indiana University Press. P. 4 for further discussion of Habermas' view of the public sphere and religion.

${ }^{x}$ For a further discussion of "visual dhikr" see Roberts, Allen F., and Mary Nooter Roberts 2007 Mystical Graffiti and the Refabulation of Dakar. Africa Today 54(2):51-77— 2008 Flickering Images, Floating Signifiers: Optical Innovation and Visual Piety in Senegal. Material Religion 4(1):4-31. 